\title{
Relationship Between Helicobacter pylori Infection and Arteriosclerosis
}

\author{
Yoshitaka Furuto (iD) \\ Mariko Kawamura \\ Jumpei Yamashita \\ Takahiro Yoshikawa \\ Akio Namikawa (D) \\ Rei Isshiki \\ Hiroko Takahashi \\ Yuko Shibuya
}

Department of Hypertension and Nephrology, NTT Medical Centre, Tokyo, Japan
Correspondence: Yoshitaka Furuto Department of Hypertension and Nephrology, NTT Medical Centre, 5-9-22, Higasi-Gotanda, Shinagawa-Ku, Tokyo, | $4 \mid-8625$, Japan

Tel +8I 03-3448-6 III

Fax +81 03-3448-6058

Email furuto19761006@yahoo.co.jp
Abstract: It is reported that Helicobacter pylori (H. pylori) infection may be linked to nondigestive tract diseases, such as arteriosclerosis including dyslipidemia, diabetes, obesity, hypertension, and cardiovascular disease. Therefore, we reviewed recent studies available in PubMed dealing with the mechanisms of arteriosclerosis due to H. pylori infection and the effects of $H$. pylori eradication. Conventional studies suggested that $H$. pylori infection may increase the risk of arteriosclerosis. A large interventional study is required to clarify the causal relationships and the effects of bacterial eradication.

Keywords: Helicobacter pylori infection, arteriosclerosis, hypertension

\section{Introduction}

While it is widely known that Helicobacter pylori (H. pylori) may cause gastritis, gastric ulcer, gastric cancer, gastric lymphoma, ${ }^{1}$ idiopathic thrombocytopenic purpura, ${ }^{2}$ and iron-deficiency anemia, ${ }^{2}$ this infection may also be involved in non-digestive tract diseases such as chronic urticaria, ${ }^{3}$ Alzheimer's disease, ${ }^{4}$ Parkinson's disease, ${ }^{5}$ atrial fibrillation, ${ }^{6}$ liver diseases, ${ }^{7}$ Behçet's disease, ${ }^{8}$ hyperemesis gravidarum, ${ }^{9}$ infertility, ${ }^{10}$ glaucoma, ${ }^{11}$ alopecia areata, ${ }^{12}$ and arteriosclerosis disease ${ }^{13}$ including dyslipidemia, ${ }^{14,15}$ diabetes, ${ }^{16-18}$ obesity, ${ }^{19,20}$ hypertension, ${ }^{15,21-23}$ chronic kidney disease ${ }^{24}$ and cardiovascular disease. ${ }^{24-29}$ Several reports have indicated a relationship between $H$. pylori and acute coronary syndrome, ${ }^{25}$ which suggests that $H$. pylori infection is a risk factor for cardiovascular disease (CVD); ${ }^{24,26,27}$ moreover, patients with $H$. pylori infection show an approximately 3-times higher risk of coronary artery disease than do healthy individuals. $^{28}$ Furthermore, in a study of $H$. pylori patients below 65 years of age, who were categorized into bacterial eradication or non-eradication groups, the eradication group showed a significantly lower incidence of coronary heart disease during a 1-year follow-up period. ${ }^{29} \mathrm{H}$. pylori infection was found to be an independent risk factor for carotid artery plaque and stroke. ${ }^{26}$

A relationship between $H$. pylori infection and lifestyle-based diseases has also been suggested. Associations of $H$. pylori infection with hypercholesterolemia, ${ }^{14}$ low levels of high-density lipoprotein-cholesterol (HDL-C), and high levels of low-density lipoprotein-cholesterol (LDL-C) have been reported. ${ }^{15}$ Several studies have found that H. pylori is associated with insulin resistance ${ }^{16}$ and diabetes mellitus. ${ }^{17,18}$ Furthermore, H. pylori infection has been reported to be positively correlated with body mass index (BMI). ${ }^{19}$ Among patients with chronic kidney disease, the risk of developing end-stage renal disease is 3.72-times higher for $H$. pylori-infected individuals than for patients without the infection. ${ }^{24}$ Hypertension has also been associated with $H$. pylori 
infection; ${ }^{15} H$. pylori-positive hypertensive patients show significantly higher arterial blood pressure than that of hypertensive patients without the infection. ${ }^{21}$ Furthermore, the eradication of $H$. pylori has been reported to improve hypertension. $^{22,23}$

Conversely, findings related to arteriosclerosis accompanied by $H$. pylori infection vary, ${ }^{5,30-39}$ and the relationship between both pathologies remains unclear. Moreover, while the precise nature of this relationship is still unclear, it is important to update this information because the eradication of $H$. pylori may be beneficial for treatment of arteriosclerosis. To fill current gaps in knowledge, we reviewed recent studies on the mechanisms of arteriosclerosis due to H. pylori infection and the effects of $H$. pylori eradication.

\section{Methods}

We performed a detailed review of the recent literature to study the relationship between $H$. pylori infection and arteriosclerosis. A literature screen was conducted by reviewing PubMed. We screened the following keywords: "Helicobacter pylori infection," and/or "eradication" with "arteriosclerosis," "hypertension," “dyslipidemia," “diabetes," "obesity," and "cardiovascular disease." We examined the mechanism of arteriosclerosis by $H$. pylori infection and the role of eradication of $H$. pylori for arteriosclerosis. Moreover, we present a narrative review of the literature obtained from these screenings as brief summary. We have described the mechanism of disease onset in detail and the most recent information on the relationship between $H$. pylori infection and arteriosclerosis.

\section{Helicobacter pylori Infection and Arteriosclerosis}

H. pylori may influence the development of arteriosclerosis due to hypertension, as suggested in previous reports. ${ }^{15,21-23}$ Two possible explanations may account for the higher incidence of hypertension in $H$. pylori-positive patients. Firstly, high-salt intake, which is a known risk factor for hypertension, favors the colonization of $H$. pylori. ${ }^{40-42}$ Moreover, experiments in mice have shown that high-salt intake facilitates the formation of $H$. pylori colonies. ${ }^{40}$ Another study revealed that high-salt intake increases the surface mucous cell mucin with an affinity to $H$. pylori, decreases the $H$. pylori-resistant gland mucous cell mucin, and damages the gastric mucosal gel layer. $^{41}$ As further proof, the 1991 EUROGAST study, which examined global $H$. pylori infection rates, revealed that the Akita region in Japan had the highest $H$. pylori infection rate $(70 \%) .{ }^{42}$ Akita is located in the Tohoku region, where the diet is known for being particularly high in salt intake compared to the rest of Japan. The high H. pylori infection rate in Akita, a developed prefecture with elevated standards of hygiene, suggests a relationship between $H$. pylori infection rate and the high-salt diet. ${ }^{43}$ Therefore, the incidence of hypertension in a region with high-salt intake may be more closely associated with $H$. pylori presence than with $H$. pylori absence, although this most likely depends also on the levels of hygiene and sociocultural factors. ${ }^{44,45}$

Secondly, since epidemiological research ${ }^{46}$ indicates that H. pylori infection may be a new risk factor for CVD, the higher prevalence of hypertension in patients with $H$. pylori infection may be a result of the existence of factors specific to $H$. pylori that also play a role in arteriosclerosis. Possible mechanisms by which atherosclerosis could be caused by $H$. pylori have been reported (Box 1). ${ }^{23,27}$ H. pylori infection was reportedly associated with increased prevalence of metabolic syndrome, CVD, and high levels of fibrinogen, total cholesterol, uric acid, and blood glucose. ${ }^{26,47}$ Moreover, H. pylori causes persistent longterm infections ${ }^{48}$ that lead to chronic inflammation, ${ }^{27,49,50}$ platelet activation, ${ }^{28,51}$ dyslipidemia, ${ }^{14,15,52}$ glucose intolerance, ${ }^{16-18,53}$ hyperhomocysteinemia, ${ }^{27,54}$ increased resorption of sodium due to elevated ammonia levels in the digestive tract, ${ }^{23}$ direct invasion of the vascular walls, ${ }^{55,56}$ and reaction in atheromas. ${ }^{28}$ Additionally, chronic inflammation due to $H$. pylori infection activates a variety of chemical mediators that have been linked to endothelial dysfunction. ${ }^{49}$ Specifically, $H$. pylori increases the levels of tumor necrosis factor (TNF)- $\alpha$, interleukin (IL)-1, IL-6, IL-8, gamma interferon, fibrinogen, thrombin, intercellular adhesion molecule, and vascular cell adhesion molecule; these inflammatory cytokines directly or indirectly damage the vascular walls, thereby causing arteriosclerosis. ${ }^{57-59}$

Box I Possible Mechanisms by Which Atherosclerosis May Be Caused by Helicobacter pylori

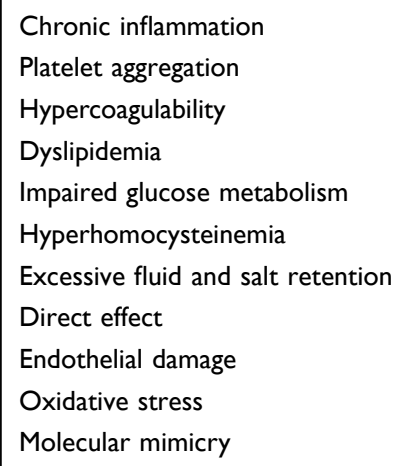

Note: Adapted from Nasrat et a ${ }^{23}$ and Vijayvergiya et al. ${ }^{27}$ 
H. pylori also causes an immune response through the activation of cyclooxygenase enzyme-2 (COX-2), which increases the production of prostaglandin and nitric oxide (NO). ${ }^{27}$ Lipopolysaccharide (LPS) on the H. pylori cell wall activates Toll-like receptor-4, which activates secondary mediators, such as mitogen-activated protein kinase, extracellularsignal-regulated kinase, c-Jun N-terminal kinase, and p38 kinase, and further stimulates NO synthase and COX-2 gene expression. $^{60,61}$ This immune response to LPS could also increase the risk of atherosclerosis. ${ }^{62}$

Another mechanism related to chronic inflammation is the antigen cross-reactivity of $H$. pylori, which has been shown to activate an autoimmune response that causes vascular endothelial damage. ${ }^{63}$ Antigenic cross-reactivity between human heat shock protein and $H$. pylori has been reported to cause coronary artery calcification and atherosclerosis; $;{ }^{64,65}$ as well as the activation of helper T-cells. ${ }^{66}$

CagA (cytotoxin-associated gene A) is a very important H. pylori virulence factor associated with a greater inflammatory response. ${ }^{67,68}$ After CagA undergoes tyrosine phosphorylation in gastric epithelial cells, it can induce a variety of cellular responses, including cell proliferation, cell movement, and suppression of cell death. ${ }^{69}$ CagA-positive $H$. pylori patients showed a higher risk of CVD and stroke. ${ }^{27,70,71}$ $\mathrm{CagA}$, at a molecular level, mimics human tropomyosin and cardiac adenosine triphosphatase that can cause myocardial damage, $;^{72,73}$ it also promotes secretion of cytokines that induce severe inflammation and atherosclerotic destabilization. ${ }^{50}$ Moreover, CagA was reported to promote arteriosclerosis by increasing the levels of COX-1 and COX-2 in the vascular endothelium, thus promoting prostacyclin production, platelet activation, ${ }^{50}$ and increased levels of oxidized LDL-C, high-sensitivity C-reactive protein (CRP), and Apolipoprotein B. $^{72}$

H. pylori infection has been reported to induce thromboxane, which activates platelets ${ }^{28}$ and promotes their binding to the Von Willebrand factor, causing platelet aggregation and destabilization of atherosclerotic plaques. ${ }^{51}$ Furthermore, TNF- $\alpha$, interferon- $\alpha$, IL-6, and IL-1, which are activated due to H. pylori infection, in turn, activate lipoprotein lipase, which can affect lipid metabolism and result in dyslipidemia. ${ }^{52}$

In relation to glucose intolerance, H. pylori-positive patients have elevated levels of the oxidative stress marker paraoxonase, suggesting a relationship between this infection and oxidative stress. ${ }^{53}$ Additionally, atrophic gastritis due to H. pylori infection leads to vitamin B12 and folic acid deficiency, which results in hyperhomocysteinemia, and damages the vascular endothelial cells. ${ }^{27}$ Increased ammonia in the intestinal tract and the accompanying intestinal spasms are induced through $H$. pylori infection, which can damage absorption within the digestive tract and result in increased resorption of sodium through the kidney, causing hypertension. ${ }^{23}$

Invasion of $H$. pylori into atheromas has been observed using PCR ${ }^{55}$ Direct $H$. pylori colonization in the arterial walls has also been suggested. ${ }^{56}$ In addition, $H$. pylori reacts with monocytes and activates the proliferation of fibroblasts in atheromas. ${ }^{28}$ Therefore, $H$. pylori has been linked to arteriosclerosis through a variety of mechanisms, thus potentially causing hypertension. $H$. pylori infection may independently be involved in atherosclerosis and hypertension through mechanisms that differ from the classical well-known causes of arteriosclerosis.

H. pylori eradication results in a variety of reported outcomes in patients. This holds true for atherosclerosisrelated disease; according to recent research (Table 1), outcomes include increased HDL-C, ${ }^{74-78}$ apolipoprotein AI, apolipoprotein AII, ${ }^{77}$ and BMI levels, ${ }^{74}$ as well as higher diastolic blood pressure, ${ }^{74}$ decreased levels of CRP,${ }^{74-76}$ fibrinogen, ${ }^{74,79}$ total oxidant status, ${ }^{80,81}$ LDL$\mathrm{C}^{75}$ total cholesterol, ${ }^{75,82}$ triglycerides, ${ }^{75}$ insulin resistance, ${ }^{75} \mathrm{BMI},{ }^{82}$ blood pressure, ${ }^{22,23}$ coronary artery lumen, ${ }^{83}$ and coronary heart disease ${ }^{29}$ and improved endothelial dysfunction ${ }^{84}$ (Table 2). Although there might be favorable effects of treating $H$. pylori on arteriosclerosis, in some studies the effects of $H$. pylori eradication on sugar, ${ }^{85}$ lipid and fibrinolytic parameters, ${ }^{85,86}$ inflammatory parameters and platelet activation markers ${ }^{87}$ were not confirmed. The contradictory results for BMI and blood pressure might be related to the study design; ${ }^{74}$ the effects of $H$. pylori eradication are controversial.

The incidence of $H$. pylori infection is influenced by social, economic, cultural, regional, and sanitary factors. Large, long-term, prospective, randomized controlled, interventional studies are required to elucidate the role of eradication for $H$. pylori infection.

\section{Conclusion}

H. pylori infection may increase the risk of arteriosclerosis through mechanisms other than those classically associated with the disease. A large interventional study is required to clarify the causal relationships and effects of bacterial eradication. 
Table I Recent Research Regarding the Role of Eradication of Helicobacter pylori in the Evolution of Atherosclerosis-Related Disease

\begin{tabular}{|c|c|c|c|c|}
\hline $\begin{array}{l}\text { First } \\
\text { Author } \\
\text { (Reference } \\
\text { No.) }\end{array}$ & Year & Country & Subjects & Outcome \\
\hline Kowalski ${ }^{83}$ & 2001 & Germany & $\begin{array}{l}100 \text { patients with coronary artery disease vs } 100 \text { patients } \\
\text { without }\end{array}$ & $\begin{array}{l}\text { Mean coronary artery lumen reduction in patients undergoing } \\
\text { percutaneous coronary angioplasty }+ \text { Helicobacter pylori } \\
\text { eradication therapy was significantly }(p<0.05) \text { smaller compared } \\
\text { to percutaneous coronary angioplasty }+ \text { placebo-treated. }\end{array}$ \\
\hline $\mathrm{Lu}^{85}$ & 2002 & Taiwan & 48 patients with gastric $H$. pylori infection & $\begin{array}{l}\text { Coronary risk factors including fasting sugar, lipid and fibrinolytic } \\
\text { profiles were not changed after successful } H \text {. pylori eradication } \\
\text { treatment. }\end{array}$ \\
\hline Yusuf $^{79}$ & 2002 & $\begin{array}{l}\text { United } \\
\text { Kingdom }\end{array}$ & $\begin{array}{l}40 \text { patients over the age of } 65 \text { years presenting with } \\
\text { symptomatic ischemic heart disease vs age-matched control } \\
\text { group of } 21 \text { patients }\end{array}$ & $\begin{array}{l}\text { The fibrinogen level decreased significantly after eradication } \\
\text { treatment of } H \text {. pylori in patients with raised fibrinogen levels } \\
(\mathrm{p}<0.01) \text {. }\end{array}$ \\
\hline Elizalde $^{86}$ & 2002 & Spain & $\begin{array}{l}487 \text { received eradication treatment vs } 199 \text { did not receive } \\
\text { eradication treatment }\end{array}$ & $\begin{array}{l}\text { H. pylori eradication has no influence on blood lipids or fibrinogen } \\
\text { levels. }\end{array}$ \\
\hline Migneco ${ }^{22}$ & 2003 & Italy & 72 hypertensive patients vs 70 normotensive controls & $\begin{array}{l}\text { A significant reduction in blood pressure after eradication of } \\
H \text {. pylori in hypertensive subjects. }\end{array}$ \\
\hline Elizalde $^{87}$ & 2004 & Spain & 92 patients with recent acute coronary syndromes & $\begin{array}{l}\text { There was not any change in inflammatory parameters or platelet } \\
\text { activation markers after } H \text {. pylori eradication in patients with } \\
\text { acute coronary syndrome. }\end{array}$ \\
\hline Scarnagl $^{77}$ & 2004 & Austria & 87 patients with duodenal ulcers & $\begin{array}{l}\text { A significant increase was observed in high-density lipoprotein } \\
\text { (HDL) cholesterol, apolipoprotein Al, and apolipoprotein All } \\
\text { after eradication. }\end{array}$ \\
\hline Kanbay $^{76}$ & 2005 & Turkey & $\begin{array}{l}78 \text { patients with } H \text {. pylori antigen positivity, } 57 \text { patients with } \\
H \text {. pylori eradication vs } 21 \text { patients without } H \text {. pylori } \\
\text { eradication }\end{array}$ & $\begin{array}{l}\text { Increase in HDL-C and reduction in CRP with successful } \\
\text { eradication }(p<0.05) \text {. }\end{array}$ \\
\hline Pellicano $^{74}$ & 2009 & Italy & $\begin{array}{l}496 \text { patients with } H \text {. pylori-positive dyspepsia and/or peptic } \\
\text { ulcer were studied after cure of the bacterium }\end{array}$ & $\begin{array}{l}\text { HDL-C increased }(p=0.02) \text { while } C \text { reactive protein and } \\
\text { fibrinogen levels diminished }(p<0.000 \mathrm{I}) \text { significantly. } B M I \text { and } \\
\text { diastolic blood pressure increased in a significant }(p=0.032 \text { and } \\
p=0.039 \text { respectively) manner compared to baseline. }\end{array}$ \\
\hline Kebapcilar $^{80}$ & 2009 & Turkey & In 33 patients, H. pylori infection was successfully eradicated & $\begin{array}{l}\text { Soluble CD40 ligand, and total oxidant status levels were } \\
\text { significantly decreased after } H \text {. pylori eradication. }\end{array}$ \\
\hline $\mathrm{Gen}^{75}$ & 2010 & Turkey & $\begin{array}{l}88 \text { patients with } H \text {. pylori infection vs } 7 / \text { patients without } \\
\text { H. pylori infection }\end{array}$ & $\begin{array}{l}\text { Improvement in insulin resistance, lipid abnormalities and CRP } \\
\text { levels with } H \text {. pylori eradication }(p<0.05) \text {. }\end{array}$ \\
\hline Nazligul $^{81}$ & 2011 & Turkey & 30 patients with $H$. pylori infection & $\begin{array}{l}\text { After eradication treatment, serum myeloperoxidase activity and } \\
\text { total oxidant status were significantly lower. }\end{array}$ \\
\hline Blum $^{84}$ & 2011 & USA & $\begin{array}{l}3 \text { I dyspeptic patients were diagnosed as } H \text {. pylori positive } \\
\text { using histopathological evaluation. II dyspeptic patients } \\
\text { were negative to } H \text {. pylori (controls). }\end{array}$ & $\begin{array}{l}\text { H. pylori eradication can improve endothelial dysfunction } \\
(p=0.001) \text { significantly. }\end{array}$ \\
\hline Jalalzadeh $^{82}$ & 2012 & Iran & $\begin{array}{l}59 \text { patients negative for } H \text {. pylori vs } 39 \text { patients positive for } \\
\text { H. pylori }\end{array}$ & $\begin{array}{l}\text { In hemodialysis patients positive for } H \text {. pylori, } 6 \text { months after } \\
\text { eradication of } H \text {. pylori, the BMI was significantly decreased } \\
(p=0.00 I) \text {. The mean serum albumin level, cholesterol, and blood } \\
\text { urea nitrogen were also significantly decreased after the } \\
\text { eradication. }\end{array}$ \\
\hline Nasrat $^{23}$ & 2015 & $\begin{array}{l}\text { Saudi } \\
\text { Arabia }\end{array}$ & $\begin{array}{l}99 \text { middle-aged male patients on treatment for essential } \\
\text { hypertension and positive for } H \text {. pylori dyspepsia }\end{array}$ & $\begin{array}{l}\text { Most patients of the study }(90.9 \%) \text { were able to discontinue } \\
\text { medication and maintain normal blood pressure values after } \\
\text { H. pylori eradication. }\end{array}$ \\
\hline
\end{tabular}

(Continued) 
Table I (Continued).

\begin{tabular}{|l|l|l|l|l|}
\hline $\begin{array}{l}\text { First } \\
\text { (Reference } \\
\text { No.) }\end{array}$ & Year & Country & Subjects & Outcome \\
\hline Wang $^{29}$ & 2018 & Taiwan & $\begin{array}{l}\text { In patients with peptic ulcer disease, 3164 patients with } \\
\text { H. pylori eradication vs } 3164 \text { patients without } H . \text { pylori } \\
\text { eradication }\end{array}$ & $\begin{array}{l}\text { There was significant difference observed in composite end- } \\
\text { points for coronary heart disease and death in early eradication } \\
\text { subgroup compared to those without eradication }(0.16 \% \text { vs } \\
0.57 \%, P=0.0133) .\end{array}$ \\
\hline Iwai ${ }^{78}$ & 2019 & Japan & $\begin{array}{l}163 \text { patients with } H . \text { pylori-associated chronic gastritis } \\
\text { H. pylori eradication therapy increased the HDL cholesterol level } \\
\text { significantly }(\mathrm{P}=0.00 \mathrm{I}) .\end{array}$ \\
\hline
\end{tabular}

Table 2 Change in Atherosclerosis Markers After Eradication of Helicobacter pylori

\begin{tabular}{|c|c|c|}
\hline & Clinical Parameter & Reference: First Author (Reference No.) \\
\hline \multirow[t]{4}{*}{ Increased } & HDL-C & Pellicano ${ }^{74}$, Gen $^{75}$, Kanbay ${ }^{76}$, Scarnag ${ }^{77}$, Iwai ${ }^{78}$ \\
\hline & Apolipoprotein AI, apolipoprotein All & Scarnagl $^{77}$ \\
\hline & BMI & Pellicano $^{74}$ \\
\hline & Diastolic blood pressure & Pellicano $^{74}$ \\
\hline \multirow[t]{3}{*}{ No Change } & Blood sugar & $\mathrm{Lu}^{85}$ \\
\hline & Lipid and fibrinolytic parameters & $\mathrm{Lu}^{85}$, Elizalde ${ }^{86}$ \\
\hline & Inflammatory parameters and platelet activation markers & Elizalde $^{87}$ \\
\hline \multirow[t]{11}{*}{ Decreased } & CRP & Pellicano ${ }^{74}$, Gen $^{75}$, Kanbay ${ }^{76}$ \\
\hline & Fibrinogen & Pellicano ${ }^{74}$, Yusuf $^{79}$ \\
\hline & Total oxidant status levels & Kebapcila $^{80}$, Nazligul ${ }^{81}$ \\
\hline & LDL-C & $\mathrm{Gen}^{75}$ \\
\hline & Total Cholesterol & Gen $^{75}$, Jalalzadeh ${ }^{82}$ \\
\hline & Triglyceride & $\mathrm{Gen}^{75}$ \\
\hline & Insulin resistance & Gen $^{75}$ \\
\hline & BMI & Jalalzadeh $^{82}$ \\
\hline & Blood pressure & Migneco $^{22}$, Nasrat $^{23}$ \\
\hline & Coronary artery lumen & Kowalski ${ }^{83}$ \\
\hline & Coronary heart disease & Wang $^{29}$ \\
\hline Improved & Endothelial dysfunction & Blum $^{84}$ \\
\hline
\end{tabular}

\section{Abbreviations}

CVD, cardiovascular disease; HDL-C, high-density lipoprotein-cholesterol; LDL-C, low-density lipoproteincholesterol; BMI, body mass index; TNF, tumor necrosis factor; IL, interleukin; COX, cyclooxygenase enzyme; LPS, lipopolysaccharide; NO, nitric oxide; CagA, cytotoxin-associated gene A; CRP, C-reactive protein.

\section{Acknowledgments}

We would like to thank Editage for English language editing.

\section{Author Contributions}

YF: Conceptualization; YF, MK, JY, TY, AN, RI, HT, and YS: Data curation; YF: Formal analysis; YF: Investigation; 
YF: Methodology; YF: Project administration; YF: Supervision; YF: Validation; YF: Roles/Writing; YF: original draft; YF: Writing; YF: review \& editing. All authors read and approved the final manuscript.

All authors made substantial contributions to conception and design, acquisition of data, or analysis and interpretation of data; took part in drafting the article or revising it critically for important intellectual content; agreed to submit to the current journal; gave final approval of the version to be published; and agree to be accountable for all aspects of the work.

\section{Funding}

This work was not supported by any funding.

\section{Disclosure}

The authors report no conflicts of interest in this work.

\section{References}

1. Nakamura S, Sugiyama T, Matsumoto T, et al.; JAPAN GAST Study Group. Long-term clinical outcome of gastric MALT lymphoma after eradication of Helicobacter pylori: a Multicentre Cohort Follow-Up Study of 420 patients in Japan. Gut. 2012;61(4):507-513. doi:10.1136/gutjnl-2011-300495

2. Pellicano R, Franceschi F, Saracco G, Fagoonee S, Roccarina D, Gasbarrini A. Helicobacters and extragastric diseases. Helicobacter. 2009;14(Suppl 1):58-68. doi:10.1111/j.1523-5378.2009.00699.x

3. Watanabe J, Shimamoto J, Kotani K. The effects of antibiotics for Helicobacter pylori eradication or dapsone on chronic spontaneous urticaria: a systematic review and meta-analysis. Antibiotics (Basel). 2021;10(2):156. doi:10.3390/antibiotics10020156

4. Beydoun MA, Beydoun HA, Elbejjani M, Dore GA, Zonderman AB. Helicobacter pylori seropositivity and its association with incident all-cause and Alzheimer's disease dementia in large national surveys. Alzheimers Dement. 2018;14(9):1148-1158. doi:10.1016/j. jalz.2018.04.009

5. Pierantozzi M, Pietroiusti A, Brusa L, et al. Helicobacter pylori eradication and 1-dopa absorption in patients with $\mathrm{PD}$ and motor fluctuations. Neurology. 2006;66(12):1824-1829. doi:10.1212/01. wnl.0000221672.01272.ba

6. Wang DZ, Chen W, Yang S, et al. Helicobacter pylori infection in Chinese patients with atrial fibrillation. Clin Interv Aging. 2015;10:813-819. doi:10.2147/CIA.S72724

7. Pellicano R, Ménard A, Rizzetto M, Mégraud F. Helicobacter species and liver diseases: association or causation? Lancet Infect Dis. 2008;8 (4):254-260. doi:10.1016/S1473-3099(08)70066-5

8. Cakmak SK, Cakmak A, Gül U, Sulaimanov M, Bingöl P, Hazinedaroğlu MS. Upper gastrointestinal abnormalities and Helicobacter pylori in Behçet's disease. Int J Dermatol. 2009;48 (11):1174-1176. doi:10.1111/j.1365-4632.2009.04145.x

9. Ng QX, Venkatanarayanan N, De Deyn MLZQ, Ho CYX, Mo Y, Yeo WS. A meta-analysis of the association between Helicobacter pylori (H.pylori) infection and hyperemesis gravidarum. Helicobacter. 2018;23(1):e12455. doi:10.1111/hel.12455

10. Ambrosini G, Andrisani A, Fiore C, et al. Anti-Helicobacter pylori antibodies in cervical mucus: a new cause of infertility. Eur J Obstet Gynecol Reprod Biol. 2011;155(2):157-160. doi:10.1016/j. ejogrb.2010.12.001
11. Bagnis A, Izzotti A, Saccà SC. Helicobacter pylori, oxidative stress and glaucoma. Dig Liver Dis. 2012;44(11):963-964. doi:10.1016/j. dld.2012.05.009

12. Campuzano-Maya G. Cure of alopecia areata after eradication of Helicobacter pylori: a new association? World $J$ Gastroenterol. 2011;17(26):3165-3170. doi:10.3748/wjg.v17.i26.3165

13. Moyaert H, Franceschi F, Roccarina D, Ducatelle R, Haesebrouck F, Gasbarrini A. Extragastric manifestations of Helicobacter pylori infection: other Helicobacters. Helicobacter. 2008;13(Suppl 1):47-57. doi:10.1111/j.1523-5378.2008.00634.x

14. Satoh H, Saijo Y, Yoshioka E, Tsutsui H. Helicobacter pylori infection is a significant risk for modified lipid profile in male subjects. J Atheroscler Thromb. 2010;17:1041-1048. doi:10.5551/jat.5157

15. Jukic A, Bozic D, Kardum D, et al. Helicobacter pylori infection and severity of coronary atherosclerosis in patients with chronic coronary artery disease. Ther Clin Risk Manag. 2017;13:933-938. doi:10.2147/ TCRM.S142193

16. Mestrovic T, Profozic Z, Profozic V. Helicobacter pylori and insulin resistance. Lijec Vjesn. 2012;134(9-10):292-296.

17. Yang GH, Wu JS, Yang YC, Huang YH, Lu FH, Chang CJ. Gastric helicobacter pylori infection associated with risk of diabetes mellitus, but not prediabetes. J Gastoroenterol Hepatol. 2014;29(10):1794-1799. doi:10.1111/jgh.12617

18. Zhou X, Zhang C, Wu J, et al. Association between Helicobacter pylori infection and diabetes mellitus: a meta-analysis of observational studies. Diabetes Res Clin Pract. 2013;99(2):200-208. doi:10.1016/j.diabres.2012.11.012

19. Xu C, Yan M, Sun Y, et al. Prevalence of Helicobacter pylori infection and its relation with body mass index in a Chinese population. Helicobacter. 2014;19(6):437-442. doi:10.1111/hel.12153

20. Thjodleifsson B, Olafsson I, Gislason D, Gislason T, Jögi R, Janson C. Infections and obesity: a Multinational Epidemiological Study. Scand J Infect Dis. 2008;40(5):381-386. doi:10.1080/ 00365540701708293

21. Wan Z, Hu L, Hu M, Lei X, Huang Y, Lv Y. Helicobacter pylori infection and prevalence of high blood pressure among Chinese adults. $J$ Hum Hypertens. 2018;32(2):158-164. doi:10.1038/s41371-017-0028-8

22. Migneco A, Ojetti V, Specchia L, et al. Eradication of Helicobacter pylori infection improves blood pressure values in patients affected by hypertension. Helicobacter. 2003;8(6):585-589. doi:10.1111/ j.1523-5378.2003.00180.x

23. Nasrat SAM, Nasrat AM. An alternative approach for the rising challenge of hypertensive illness via Helicobacter pylori eradication. Cardiol Res. 2015;6(1):221-225. doi:10.14740/cr382e

24. Lin SY, Lin CL, Liu JH, Yang YF, Huang CC, Kao CH. Association between Helicobacter pylori infection and the subsequent risk of end-stage renal disease: a Nationwide Population-Based Cohort Study. Int J Clin Pract. 2015;69(5):604-610. doi:10.1111/ijcp.12602

25. Eskandarian R, Ghorbani R, Shiyasi M, Momeni B, Hajifathalian K, Madani M. Prognostic role of Helicobacter pylori infection in acute coronary syndrome: a Prospective Cohort Study. Cardiovasc J Afr. 2012;23(3):131-135. doi:10.5830/CVJA-2011-016

26. Longo-Mbenza B, Nsenga JN, Mokondjimobe E, et al. Helicobacter pylori infection is identified as a cardiovascular risk factor in Central Africans. Vasc Health Risk Manag. 2012;8:455-461. doi:10.2147/ VHRM.S28680

27. Viayvergiya R, Vadivelu R. Role of Helicobacter pylori infection in pathogenesis of atherosclerosis. World J Cardiol. 2015;7(3):134-143. doi:10.4330/wjc.v7.i3.134

28. Rogha M, Nikvarz M, Pourmoghaddas Z, Shirneshan K, Dadkhah D, Pourmoghaddas M. Is Helicobacter pylori infection a risk factor for coronary heart disease? ARYA Atheroscler. 2012;8(1):5-8.

29. Wang JW, Tseng KL, Hsu CN, et al. Association between Helicobacter pylori eradication and the risk of coronary heart diseases. PLoS One. 2018;13(1):e0190219. doi:10.1371/journal. pone.0190219 
30. Whincup PH, Mendall MA, Perry IJ, Strachan DP, Walker M. Prospective relations between Helicobacter pylori infection, coronary heart disease and stroke in middle-aged men. Heart. 1997;77(3):294. doi:10.1136/hrt.77.3.294

31. Heuschmann PU, Neureiter D, Gesslein M, et al. Association between infection with Helicobacter pylori and chlamydia pneumoniae and risk of ischemic stroke subtypes. Stroke. 2001;32 (10):2253-2258. doi:10.1161/hs1001.097096

32. Mayr M, Kjechl S, Tsimikas S, et al. Oxidized low-density lipoprotein autoantibodies, chronic infections, and carotid atherosclerosis in a population-based study. $J$ Am Coll Cardiol. 2006;47 (12):2436-2443. doi:10.1016/j.jacc.2006.03.024

33. Akbas HS, Basyigit S, Suleymanlar I, et al. The assessment of carotid intima media thickness and serum paraoxonase- 1 activity in Helicobacter pylori positive subjects. Lipids Health Dis. 2010;9 (1):92. doi:10.1186/1476-511X-9-92

34. Oluyemi A, Anomneze E, Smith S, Fasanmade O. Prevalence of a marker of active Helicobacter pylori infection among patients with type 2 diabetes mellitus in Lagos, Nigeria. BMC Res Notes. 2012;5(1):284. doi:10.1186/1756-0500-5-284

35. Cho I, Blaser MJ, Francois F, et al. Helicobacter pylori and overweight status in the United States: data from the third national health and nutrition examination survey. Am J Epidemiol. 2005;162 (6):579-584. doi:10.1093/aje/kwi237

36. Kong X, Xu D, Li F, Ma X, Su H, Xu D. Association of H. pylori infection with chronic kidney disease among Chinese adults. Int Urol Nephrol. 2017;49(5):845-850. doi:10.1007/s11255-016-1498-2

37. Sotuneh N, Hosseini SR, Shokri-Shirvani J, Bijani A, Ghadimi R. Helicobacter pylori infection and metabolic parameters: is there an association in elderly population? Int J Prev Med. 2014;5 (12):1537-1542.

38. Kopacova M, Koupil I, Seifert B, et al. Blood pressure and stature in Helicobacter pylori positive and negative persons. World $J$ Gastroenterol. 2014;20(19):5625-5631. doi:10.3748/wjg.v20. i19.5625

39. Danesh J, Peto R. Risk factors for coronary heart disease and infection with Helicobacter pylori: meta-analysis of 18 studies. BMJ. 1998;316(7138):1130-1132. doi:10.1136/bmj.316.7138.1130

40. Fox JG, Dangler CA, Taylor NS, King A, Koh TJ, Wang TC. Highsalt diet induces gastric epithelial hyperplasia and parietal cell loss, and enhances Helicobacter pylori colonization in C57BL/6 mice. Cancer Res. 1999;59(19):4823-4828.

41. Kato S, Tsukamoto T, Mizoshita T, et al. High salt diets dose-dependently promote gastric chemical carcinogenesis inHelicobacter pylori-infected Mongolian gerbils associated with a shift in mucin production from glandular to surface mucous cells. Int $J$ Cancer. 2006;119(7):1558-1566. doi:10.1002/ijc.21810

42. The EUROGAST Study Group. An international association between Helicobacter pylori infection and gastric cancer. Lancet. 1993;341 (8857):1359-1362. doi:10.1016/0140-6736(93)90938-D

43. Dahl LK. Possible role of salt intake in the development of essential hypertension. Int J Epidemiol. 2005;34(5):967-972. doi:10.1093/ije/ dyh317

44. Asaka M, Kimura T, Kudo M, et al. Relationship of Helicobacter pylori to serum pepsinogens in an asymptomatic Japanese population. Gastroenterology. 1992;102(3):760-766. doi:10.1016/0016-5085(92) 90156-S

45. Lee YY, Ismail AW, Mustaffa N, et al. Sociocultural and dietary practices among Malay subjects in the north-eastern region of Peninsular Malaysia: a region of low prevalence of Helicobacter pylori infection. Helicobacter. 2012;17(1):54-61. doi:10.1111/ j.1523-5378.2011.00917.x

46. Longo-Mbenza B, Mambune HF, Kasiam JB, et al. Relationship between waist circumference and cholesterol in Central Africans with congestive heart failure. West Afr J Med. 2007;26(3):183-190. doi:10.4314/wajm.v26i3.28306
47. Longo-Mbenza B, Nkondi NJ, Vangu ND. Prevention of the metabolic syndrome insulin resistance and the atherosclerotic diseases in Africans infected by Helicobacter pylori infection and treated by antibiotics. Int $J$ Cardiol. 2007;121(3):229-238. doi:10.1016/j. ijcard.2006.12.003

48. Cammarota G, Pasceri V, Gasbarrini A, Gasbarrini G. Helicobacter pylori is an aetiological factor for ischaemic heart disease: the case against. Dig Liver Dis. 2000;32(1):65-68. doi:10.1016/S15908658(00)80047-X

49. Coskun S, Kasirga E, Yilmaz O, et al. Is Helicobacter pylori related to endothelial dysfunction during childhood? Pediatr Int. 2008;50 (2):150-153. doi:10.1111/j.1442-200X.2008.02542.x

50. Rogha M, Dadkhah D, Pourmoghaddas Z, Shirneshan K, Nikvarz M, Pourmoghaddas M. Association of Helicobacter pylori infection with severity of coronary heart disease. ARYA Atheroscler. 2011;7:138-141.

51. Fagoonee S, De Angelis C, Elia C, et al. Potential link between Helicobacter pylori and ischemic heart disease: does the bacterium elicit thrombosis? Minerva Med. 2010;101(2):121-125.

52. Albaker WI. Helicobacter pylori infection and its relationship to metabolic syndrome: is it a myth or fact? Saudi J Gastroenterol. 2011;17(3):165-169. doi:10.4103/1319-3767.80377

53. Aslan M, Nazligul Y, Horoz M, et al. Serum paraoxonase-1 activity in Helicobacter pylori infected subjects. Atherosclerosis. 2008;196 (1):270-274. doi:10.1016/j.atherosclerosis.2006.10.024

54. Tamura A, Fujioka T, Nasu M. Relation of Helicobacter pylori infection to plasma vitamin B12, folic acid, and homocysteine levels in patients who underwent diagnostic coronary arteriography. Am $J \quad$ Gastroenterol. 2002;97(4):861-866. doi:10.1111/j.15720241.2002.05601.x

55. Martinez Torres A, Martínez Gaensly M. Helicobacter pylori: ¿un nuevo factor de riesgo cardiovascular? Rev Esp Cardiol. 2002;55 (6):652-656. doi:10.1016/S0300-8932(02)76673-6

56. Murray LJ, Bamford KB, Kee F, et al. Infection with virulent strains of Helicobacter pylori is not associated with ischaemic heart disease: evidence from a population-based case-control study of myocardial infarction. Atherosclerosis. 2000;149(2):379-385. doi:10.1016/ S0021-9150(99)00325-1

57. Consolazio A, Borgia MC, Ferro D, et al. Increased thrombin generation and circulating levels of tumour necrosis factor- $\alpha$ in patients with chronic Helicobacter pylori-positive gastritis. Aliment Pharmacol Ther. 2004;20(3):289-294. doi:10.1111/j.13652036.2004.02074.x

58. Russo F, Jirillo E, Clemente C, et al. Circulating cytokines and gastrin levels in asymptomatic subjects infected by Helicobacter pylori (H. pylori). Immunopharmacol Immunotoxicol. 2001;23 (1):13-24. doi:10.1081/IPH-100102563

59. Maciorkowska E, Kaczmarski M, Panasiuk A, Kondej-Muszynska K, Kemonai A. Soluble adhesion molecules ICAM-1, VCAM-1, P-selectin in children with Helicobacter pylori infection. World J Gastroenterol. 2005;11(43):6745-6750. doi:10.3748/wjg.v11. i43.6745

60. Slomiany BL, Slomiany A. Involvement of p38 MAPK-dependent activator protein (AP-1) activation in modulation of gastric mucosal inflammatory responses to Helicobacter pylori by ghrelin. Inflammopharmacology. 2013;21(1):67-78. doi:10.1007/s10787012-0141-9

61. Slomiany BL, Slomiany A. Induction in gastric mucosal prostaglandin and nitric oxide by Helicobacter pylori is dependent on MAPK/ ERK-mediated activation of IKK- $\beta$ and cPLA2: modulatory effect of ghrelin. Inflammopharmacology. 2013;21(3):241-251. doi:10.1007/ s10787-013-0169-5

62. Grebowska A, Rechcinski T, Bak-Romaniszyn L, et al. Potential role of LPS in the outcome of Helicobacter pylori related diseases. Pol J Microbiol. 2006;55(1):25-30. 
63. Rechcinski T, Kasprzak JD, Chmiela M, Krzeminska-Pakula M, Rudnicka W. Patients with unstable angina pectoris present increased humoral response against Helicobacter pylori in comparison with patients with aggravated dyspepsia. Acta Microbial Pol. 2002;51:339-344.

64. Strachan DP. Non-gastrointestinal consequences of Helicobacter pylori infection. Br Med Bull. 1998;54(1):87-93. doi:10.1093/oxfordjournals.bmb.a011684

65. Zhu J, Katz RJ, Quyyumi AA, et al. Association of serum antibodies to heat-shock protein 65 with coronary calcification level: suggestion of pathogen-triggered autoimmunity in early atherosclerosis. Circulation. 2004;109(1):36-41. doi:10.1161/01.CIR.00001055 13.37677.B3

66. Ayada K, Yokota K, Kobayashi K, Shoenfeld Y, Matsuura E, Oguma K. Chronic infection and atherosclerosis. Clin Rev Allergy Immunol. 2009;37(1):44-48. doi:10.1007/s12016-008-8097-7

67. Jafarzadeh A, Hassanshahi GH, Nemati M. Serum levels of high-sensitivity C-reactive protein (hs-CRP)in Helicobacter pylori-infected peptic ulcer patients and its association with bacterial CagA virulence factor. Dig Dis Sci. 2009;54(12):2612-2616. doi:10.1007/s10620-008-0686-Z

68. Niccoli G, Franceschi F, Cosentino N, et al. Coronary atherosclerotic burden in patients with infection by CagA-positive strains of Helicobacter pylori. Coron Artery Dis. 2010;21(4):217-221. doi:10.1097/MCA.0b013e3283399f36

69. Suzuki M, Mimuro H, Kiga K, et al. Helicobacter pylori CagA phosphorylation-independent function in epithelial proliferation and inflammation. Cell Host Microbe. 2009;5(1):23-34. doi:10.1016/j. chom.2008.11.010

70. Tamer GS, Tengiz I, Ercan E, Duman C, Alioglu E, Turk UO. Helicobacter pylori seropositivity in patients with acute coronary syndromes. Dig Dis Sci. 2009;54(6):1253-1256. doi:10.1007/ s10620-008-0482-9

71. Zhang S, Guo Y, Ma Y, Teng Y. Cytotoxin-associated gene-A-seropositive virulent strains of Helicobacter pylori and atherosclerotic diseases: a systematic review. Chin Med J (Engl). 2008;121(10):946-951. doi:10.1097/00029330-200805020-00015

72. Huang B, Chen Y, Xie Q, et al. CagA-positive Helicobacter pylori strains enhanced coronary atherosclerosis by increasing serum OxLDL and HsCRP in patients with coronary heart disease. Dig Dis Sci. 2011;56(1):109-114. doi:10.1007/s10620-010-1274-6

73. Figura N, Palazzuoli A, Vaira D, et al. Cross-sectional study: cagApositive Helicobacter pylori infection, acute coronary artery disease and systemic levels of B-type natriuretic peptide. J Clin Pathol. 2014;67(3):251-257. doi:10.1136/jclinpath-2013-201743

74. Pellicano R, Oliaro E, Fagoonee S, et al. Clinical and biochemical parameters related to cardiovascular disease after Helicobacter pylori eradication. Int Angiol. 2009;28(6):469-473.

75. Gen R, Demir M, Ataseven H. Effect of Helicobacter pylori eradication on insulin resistance, serum lipids and low-grade inflammation. South Med J. 2010;103(3):190-196. doi:10.1097/SMJ.0b013e3181cf373f
76. Kanbay M, Gür G, Yücel M, Yilmaz U, Bayacioglu S. Does eradication of Helicobacter pylori infection help normalize serum lipid and CRP levels? Dig Dis Sci. 2005;50(7):1228-1231. doi:10.1007/ s10620-005-2764-9

77. Scharnagl H, Kist M, Grawitz AB, Koenig W, Wieland H, März W. Effect of Helicobacter pylori eradication on high-density lipoprotein cholesterol. Am J Cardiol. 2004;93(2):219-220. doi:10.1016/j. amjcard.2003.09.045

78. Iwai N, Okuda $\mathrm{T}$, Oka $\mathrm{K}$, et al. Helicobacter pylori eradication increases the serum high density lipoprotein cholesterol level in the infected patients with chronic gastritis: a Single-Center Observational Study. PLoS One. 2019;14(8):e0221349. doi:10.1371/journal. pone. 0221349

79. Yusuf SW, Mishra RM. Effect of Helicobacter pylori infection on fibrinogen level in elderly patients with ischaemic heart disease. Acta Cardiol. 2002;57(5):317-322. doi:10.2143/AC.57.5.2005446

80. Kebapcilar L, Sari I, Renkal AH, et al. The influence of Helicobacter pylori eradication on leptin, soluble CD40 ligand, oxidative stress and body composition in patients with peptic ulcer disease. Intern Med. 2009;48(24):2055-2059. doi:10.2169/internalmedicine.48.2562

81. Nazligul Y, Aslan M, Horoz M, et al. The effect on serum myeloperoxidase activity and oxidative status of eradication treatment in patients Helicobacter pylori infected. Clin Biochem. 2011;44(8-9):647-649. doi:10.1016/j.clinbiochem.2011.03.001

82. Jalalzadeh M, Ghadiani MH, Mousavinasab N. Association between Helicobacter pylori infection and body mass index, before and after eradication of infection in hemodialysis batients. $J$ Nephropathol. 2012;1(3):170-176. doi:10.5812/nephropathol.8115

83. Kowalski M. Helicobacter pylori (H. pylori) infection in coronary artery disease: influence of $H$. pylori eradication on coronary artery lumen after percutaneous transluminal coronary angioplasty. The detection of $H$. pylori specific DNA in human coronary atherosclerotic plaque. $J$ Physiol Pharmacol. 2001;52(1 Suppl 1):3-31.

84. Blum A, Tamir S, Mualem K, Ben-Shushan RS, Keinan-Boker L, Paritsky M. Endothelial dysfunction is reversible in Helicobacter pylori-positive subjects. Am J Med. 2011;124(12):1171-1174. doi:10.1016/j.amjmed.2011.08.015

85. Lu YH, Yen HW, Lin TH, et al. Changes of coronary risk factors after eradication of Helicobacter pylori infection. Kaohsiung J Med Sci. 2002;18(6):266-272.

86. Elizalde JI, Piqué JM, Moreno V, et al.; Group of Study on Oesophageal and Gastric Diseases from The Spainish Gastroenterological Association. Influence of Helicobacter pylori infection and eradication on blood lipids and fibrinogen. Aliment Pharmacol Ther. 2002;16(3):577-586. doi:10.1046/j.13652036.2002.01202.x

87. Elizalde JI, Pérez-Pujol S, Heras M, et al. Effects of Helicobacter pylori eradication on platelet activation and disease recurrence in patients with acute coronary syndromes. Helicobacter. 2004;9 (6):681-689. doi:10.1111/j.1083-4389.2004.00271.x
International Journal of General Medicine

\section{Publish your work in this journal}

The International Journal of General Medicine is an international, peer-reviewed open-access journal that focuses on general and internal medicine, pathogenesis, epidemiology, diagnosis, monitoring and treatment protocols. The journal is characterized by the rapid reporting of reviews, original research and clinical studies across all disease areas. The manuscript management system is completely online and includes a very quick and fair peer-review system, which is all easy to use. Visit http://www.dovepress.com/ testimonials.php to read real quotes from published authors. 